\title{
High genetic connectivity across the Indian and Pacific Oceans in the reef fish Myripristis berndti (Holocentridae)
}

\author{
Matthew T. Craig ${ }^{1, *}$, Jeff A. Eble ${ }^{1}$, Brian W. Bowen ${ }^{1}$, D. Ross Robertson ${ }^{2}$ \\ ${ }^{1}$ Hawaii Institute of Marine Biology, PO 1346, Kaneohe, Hawaii 96744, USA \\ ${ }^{2}$ Smithsonian Tropical Research Institute, Balboa, Republic of Panamá
}

\begin{abstract}
To assess patterns of connectivity among populations of an Indo-Pacific reef fish, we surveyed mtDNA of the bigscale soldierfish Myripristis berndti (Holocentridae), which is concentrated on reefs at intermediate depths, but occurs to at least $160 \mathrm{~m}$. Our multi-scale approach included sampling at 11 sites spanning the entire range of the species from the western Indian Ocean to the eastern Pacific, across $240^{\circ}$ of longitude (total $\mathrm{N}=278$ ), and 9 islands throughout one of the largest and most isolated archipelagos, the Hawaiian Islands (subtotal $\mathrm{N}=147$ ). Analysis of cytochrome $b$ sequences demonstrated the following: (1) common haplotypes are shared among all sample localities, (2) there is modest population structure across the entire species range $\left(\Phi_{\mathrm{st}}=0.211 ; \mathrm{p}<0.001\right)$, (3) there is no structure among the Hawaiian Islands $\left(\Phi_{\mathrm{st}}=0.0004 ; \mathrm{p}=0.4107\right)$, and (4) there is no structure across the central-west Pacific $\left(\Phi_{\mathrm{st}}=-0.007, \mathrm{p}=0.634\right)$. Population separations across the East Pacific Barrier were significant (overall $\Phi_{\mathrm{st}}=0.278, \mathrm{p}<0.001$; pairwise range $\Phi_{\mathrm{st}}=0.107$ to 0.424 ), yet significantly weaker than those across the Indo-Pacific Barrier (overall $\Phi_{\text {st }}=0.583, p<0.001$; pairwise range $\Phi_{\mathrm{st}}=0.329$ to 0.810 ; Mann-Whitney $U$-test, $\mathrm{p}<0.001$ ). When grouped by major biogeographic province, populations showed no difference within the central-west Pacific $\left(\Phi_{\mathrm{st}}=-0.007, \mathrm{p}=\right.$ $0.634)$, within the Indian Ocean $\left(\Phi_{\mathrm{st}}=-0.027, \mathrm{p}=0.528\right)$, or within the east Pacific $\left(\Phi_{\mathrm{st}}=-0.061, \mathrm{p}=\right.$ 0.920). Mismatch distributions and coalescence analysis indicated a rapid population expansion on the order of $\sim 500000 \mathrm{yr}$ before present (range 300000 to $10^{6} \mathrm{yr}$ depending on mutation rate). Despite having a vast distribution and broad depth range, $M$. berndti shows the genetic signatures of a population bottleneck and recovery similar to shallow reef specialists that were displaced or extirpated during glacial maxima. Overall, the mtDNA data indicated a dispersal capability in $M$. berndti which far exceeds that of typical reef fishes. While recent genetic studies demonstrate limited larval dispersal in some reef fishes, it is clear that others, including soldierfishes, are extensive dispersers.
\end{abstract}

KEY WORDS: Phylogeography · East Pacific Barrier · Soldierfish · Indo-Pacific Barrier · Hawaii

\section{INTRODUCTION}

Characterizing gene flow in the marine environment is a troublesome task as the potential for dispersal far exceeds that in the terrestrial environment. Physical barriers to dispersal in the oceans are few, although notable exceptions such as the Isthmus of Panama have been studied in detail and have yielded insights into the process of allopatric speciation (e.g. Bermingham et al. 1997, Knowlton \& Weigt 1998, Craig et al.
2004). Most reef-associated organisms have limited mobility as adults, thus long-distance dispersal is accomplished during pelagic early life history phases, i.e. eggs, larvae, juveniles. Consequently, the duration and dispersal capabilities of early life stages have been the cornerstone of marine connectivity theory (Ekman 1953, Scheltema 1968, Crisp 1978). While the simplest expectation is that an increased pelagic larval duration (PLD) corresponds to increasing population connectivity, recent studies have shown that long PLD may not 
always confer high levels of genetic connectivity, and that recruitment to or near natal reefs may be common (e.g. Jones et al. 2005, Taylor \& Hellberg 2005).

The soldierfishes (Holocentridae; Myripristinae) are abundant members of tropical reef assemblages (Wyatt 1983), residing in caves and reef crevices during the day and foraging on the reef flat or in the water column at night (Greenfield 1968, Randall \& Greenfield 1996). Myripristis is a pantropical genus comprised of 23 species (Randall \& Greenfield 1996). The bigscale solderfish Myripristis berndti Jordan \& Evermann 1903 is the largest member of the genus, occurring from East Africa to the Pacific shore of the Americas. This geographic range makes $M$. berndti one of the most widely distributed reef fishes (Randall \& Greenfield 1996, Robertson et al. 2004). M. berndti is common between 10 and $50 \mathrm{~m}$ depth, although its range extends to at least $160 \mathrm{~m}$ (Chave \& Mundy 1994). The species is regularly taken by fishermen in the Hawaiian Islands and elsewhere and is often found under reef ledges with several other Myripristis species.

The PLD of most holocentrids is unknown; however, Tyler et al. (1993) estimated a PLD of 40 to $58 \mathrm{~d}$ for the Atlantic species, Myripristis jacobus, and preliminary examination of $M$. berndti otoliths indicates a PLD of about 55 d (B. Victor unpubl. data). Juveniles of Myripristis spp. from Rangiroa show a variable size at settlement from 20 to $45 \mathrm{~mm}$ standard length (B. Victor unpubl. data) and Leis \& CarsonEwert (1997) report collecting juveniles up to $55 \mathrm{~mm}$ standard length, indicating some flexibility in pelagic juvenile duration. All species in the family pass through a unique 'rhynchichthys' pelagic juvenile stage that is characterized by extreme cranial spination (Tyler et al. 1993).

The wide range of Myripristis berndti spans 3 major biogeographic regions: the Indian Ocean (IO), the central-western Pacific (CWP), and the tropical eastern Pacific (TEP) (sensu Briggs 1974). The barriers between these provinces include the world's largest uninterrupted expanse of deep ocean, the 4000 to 7000 km wide East Pacific Barrier (EPB) (sensu Briggs 1974), which isolates the TEP from the rest of the Pacific, and the Indo-Pacific Barrier (IPB), the dense mass of islands and continents, including Australia, that separates the Indian and Pacific Oceans. This latter barrier is enhanced during low sea-level stands, when there are fewer passages between islands, and by strong upwelling that is likely to reduce the habitat available for tropical species (Fleminger 1986, Barber et al. 2002). M. berndti thus provides an opportunity to compare the effectiveness of these geographic barriers, as well as the oceanic distances, on population connectivity.
Plio-pleistocene climate shifts evidently affected the distribution of many species, both terrestrial and marine (e.g. Roy et al. 1996, Hellberg et al. 2001). As sea levels rose and fell with the formation and retreat of glacial ice, shallow water habitat was altered, often resulting in reduced area or shifting environmental regimes. Studies on the genetic consequences of glacial range shifts (e.g. Klicka \& Zink 1997, Fauvelot et al. 2003) indicate a reduction in genetic diversity in response to habitat loss and concomitant population bottlenecks, a pattern commonly observed in shallow reef fishes. Myripristis berndti has a widespread distribution, both geographically and across depth contours. Hence a goal of this research is to determine whether broad distributions have protected soldierfishes from population crashes detected in species that are limited to the shallowest reef habitats (Grant \& Bowen 1998, Durand et al. 2005).

Lastly, the vast range of this species provides an opportunity to implement a multi-scale approach to population connectivity, allowing for exploration of gene flow at scales ranging from islands within an isolated archipelago to reefs scattered across the breadth of 2 interlinked ocean basins. Here we use DNA sequence data from the mitochondrial cytochrome $b$ gene to examine phylogeography in Myripristis berndti. We posed the following questions: (1) Does the vast geographic range of this species indicate strong population connectivity? (2) Does the ability to occupy both shallow and deep reefs mitigate the impact of past climate changes on the population genetic architecture of a species? (3) Does M. berndti show significant population structure on the scale of the Northwestern Hawaii Islands Marine National Monument (NWHIMNM), the largest marine protected area in the United States? We addressed these questions on an archipelago scale by surveying 9 locations scattered across the $2500 \mathrm{~km}$ length of the Hawaiian Islands $(\mathrm{N}=147)$ and on a 'global' scale by including 11 additional sites across $23000 \mathrm{~km}$ between the western Indian Ocean and eastern Pacific Ocean (total $\mathrm{N}=278$ ) (Fig. 1).

\section{MATERIALS AND METHODS}

Specimens of Myripristis berndti were collected by SCUBA divers using polespears. Tissue samples (pectoral-fin clips) were preserved in saturated DMSO/ $\mathrm{NaCl}$ solution (20\% DMSO, 0.25M EDTA) at $\mathrm{pH} 8.0$ and stored at ambient temperature. Total genomic DNA was isolated with the DNEasy isolation kit (Qiagen) following manufacturer's protocols. Extracted DNA was frozen in TE buffer and archived at $-20^{\circ} \mathrm{C}$. Approximately 700 base pairs of mitochondrial cyto- 


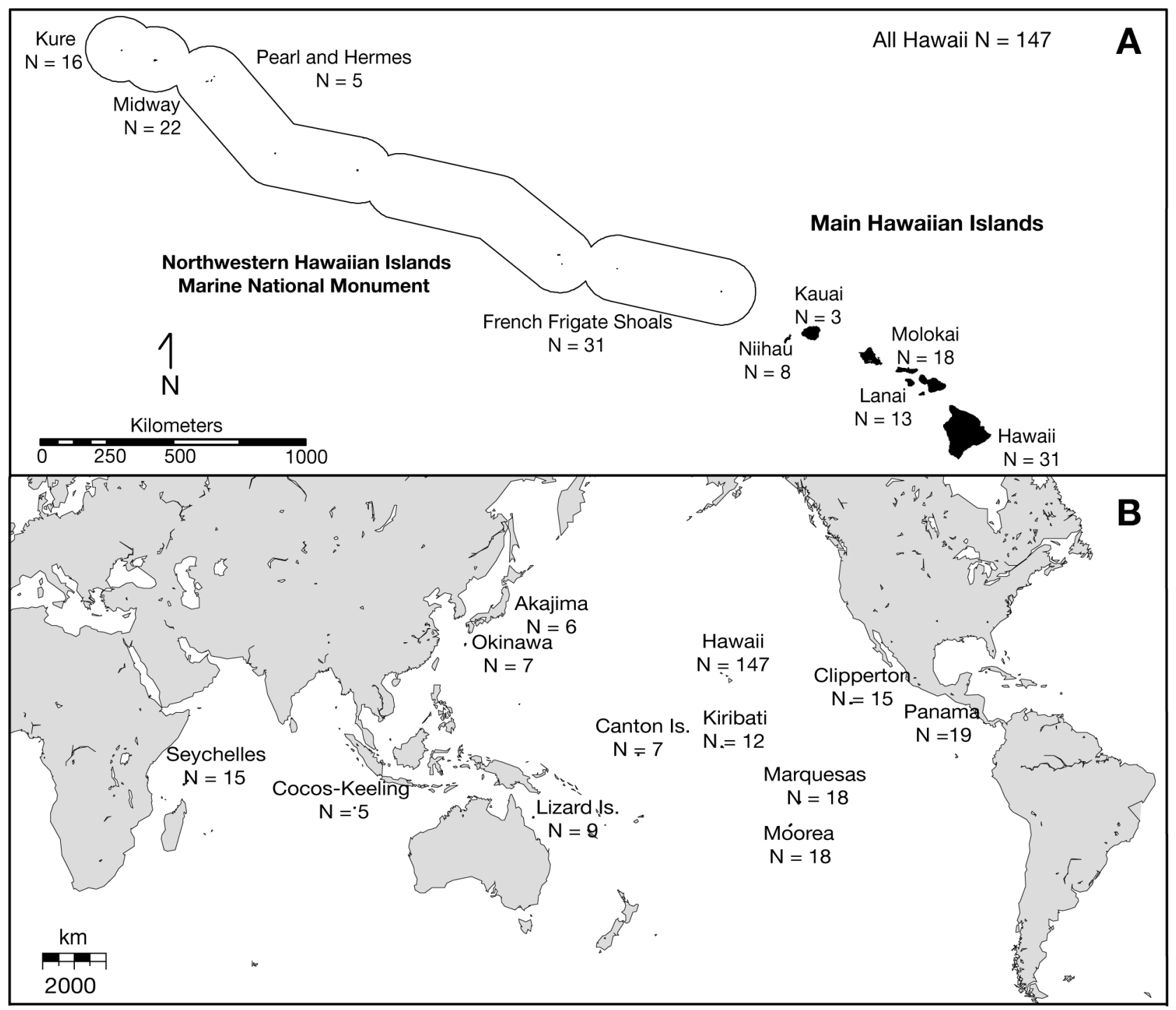

Fig. 1. Myripristis berndti. Sampling localities and sample size for 278 individuals. (A) Hawaiian Islands (solid line marks boundaries of the Northwestern Hawaiian Islands Marine National Monument); (B) Indian and Pacific Oceans

chrome $b$ were amplified using a heavy strand primer (5'-GTGACTTGAAAAACCACCGTTG-3') and a light strand primer (5'-AATAGGAAGTATCATTCGGGTTT GATG-3') designed by Song et al. (1998) and Taberlet et al. (1992) respectively.

Polymerase chain reaction (PCR) amplification mixes consisted of $3.0 \mathrm{mM} \mathrm{MgCl} 2,0.26 \mu \mathrm{M}$ of each primer, $50 \mathrm{nM}$ dNTPs, $0.20 \mu \mathrm{l}$ Taq DNA polymerase and $5.0 \mu \mathrm{l}$ of $10 \times$ PCR buffer (Bioline) in $50 \mu$ l total volume. PCR reactions utilized the following cycling parameters: an initial denaturing step at $94^{\circ} \mathrm{C}$ for $4 \mathrm{~min}$, then 35 cycles of amplification (30 s of denaturation at $94^{\circ} \mathrm{C}, 30 \mathrm{~s}$ of annealing at $50^{\circ} \mathrm{C}$, and $1 \mathrm{~min}$ of extension at $72^{\circ} \mathrm{C}$ ) and a final extension of $4 \mathrm{~min}$ at $72^{\circ} \mathrm{C}$. Excess oligonucleotide primers were removed with exonuclease I and shrimp alkaline phosphatase (ExoSAP; USB). Sequencing reactions with fluorescently-labeled dideoxy terminators were performed according to manufacturer's recommendations and analyzed with an ABI 3100 Genetic Analyzer (Applied Biosystems) at the Hawaii Institute of Marine Biology Sequencing Core Facility. Unique haplotypes were deposited in GenBank (DQ868393-DQ868429).

Haplotype diversity $(h)$ and nucleotide diversity $(\pi)$ were calculated for each site and for the overall sample group using the algorithms in Nei (1987) as implemented in the computer program Arlequin V. 3.00 (L. Excoffier, G. Laval, \& S. Schneider, Computational and Molecular Population Genetics Lab, Institute of Zoology, University of Berne, Switzerland). Neutrality 
(equilibrium) was assessed by calculating Tajima's D for each population (Tajima 1989). Tajima's D gives an estimate of the population demographics; a negative value indicates an overabundance of low-frequency haplotypes, a possible signature of recent demographic expansion. Significance was tested using 1000 permutations in Arlequin V. 3.00. A statistical parsimony network was constructed using the computer program TCS (V. 1.21; Clement et al. 2000) with default settings. We used mismatch distributions for the overall dataset and for the Hawaii-only dataset to differentiate between past population expansion or stasis models. When a unimodal distribution was found (indicative of a rapidly expanding population) we followed Li (1977) and Rogers \& Harpending (1992) and fitted estimates of $\tau, \theta_{0}$, and $\theta_{1}$ to observed mismatch distributions in order to determine effective population sizes and time to coalescence. Coalescence analysis requires an estimate of generation time and mutation rate. Divergence estimates for cytochrome $b$ have been obtained for some reef fishes $\left(2 \%\right.$ per $10^{6} \mathrm{yr}$ between lineages, $1 \%$ within lineages; Bowen et al. 2001, 2006a) and we provisionally apply this rate to estimate divergence times. Generation time in many reef fishes is unknown, including $M$. berndti, but we provisionally follow Bowen et al. (2006a) and use 3 yr as an initial estimate. Given the imprecision of estimates of mutation rate and generation time, we caution that the corresponding age and effective population size $\left(N_{\mathrm{e}}\right)$ be interpreted only as first order approximations.

Population structure was assessed on 2 geographic scales. First we examined genetic structure throughout the Hawaiian Islands. Samples from those islands were initially treated as a single group with 9 locations, and later partitioned by their relative position in the chain (Northwestern or main Hawaiian Islands). The latter treatment allowed for an assessment of connectivity between 2 regions that vary in terms of their level of fishing pressure, oceanography and ecology (Friedlander \& DeMartini 2002). Second, we examined samples from the entire range of the species; $\Phi_{\mathrm{st}}$ values were calculated using Arlequin for the entire sample group and in a pairwise fashion for all sample localities. For the 'global' comparisons, concern arose as to the effects of including all Hawaiian samples $(\mathrm{N}=147)$ in calculations of fixation indices as they constituted a large proportion of the overall sample size $(\mathrm{N}=278)$. In order to examine the effects of sample bias due to disproportionate sampling in this region we examined the global data first using one sample site from the island of Hawaii $(\mathrm{N}=31)$ and then with all Hawaiian sample sites.

Lastly, samples across the range were grouped by major biogeographic province (TEP, CEP, IO) followed by calculation of fixation indices. This set of groupings allowed for examination of hypothesized barriers to gene flow between larger groups of populations within an Analysis of Molecular Variance (AMOVA) framework.

\section{RESULTS}

We resolved 644 base pairs of mtDNA cytochrome $b$ from 278 individuals from throughout the range of Myripristis berndti. We observed 37 haplotypes among all samples which resulted from 33 transitions and 4 transversions; see online supplementary material for an alignment of haplotypes and frequency data (www.int-res.com/articles/suppl/m334p245_app/). A statistical parsimony network demonstrated a cluster of closely related haplotypes (Fig. 2). The most common haplotype was detected at every site except Cocos-Keeling Island (Indian Ocean; $\mathrm{N}=5$ ), and the second most common haplotype was detected at all locations (Fig. 2).

For the Hawaiian dataset, the fixation index for the 9 island samples was $\Phi_{\text {st }}=0.0004(p=0.385)$. When grouped by relative position in the archipelago (4 sites from the Northwestern Hawaiian Islands versus 5 sites from main 8 islands) the fixation index rose marginally to $\Phi_{\mathrm{st}}=0.005$, yet was still non-significant $(\mathrm{p}=0.414)$. For all Hawaiian samples, nucleotide diversity was $\pi=0.002$, and haplotype diversity was $h=0.553$ (Table 1). Mismatch distribution (Fig. 3) for the Hawaiian samples was unimodal (Harpending's raggedness index $r=0.09, \mathrm{p}=0.850$ ) and yielded values of $\tau=0$, $\theta_{0}=1.273$ and $\theta_{1}=1.273$.

Fixation index $\left(\Phi_{\mathrm{st}}\right)$ for the range wide dataset that included only 1 sample site from the Hawaiian Islands (the island of Hawaii) was $\Phi_{\text {st }}=0.258$ and was significant $(p<0.001)$. When all samples from the Hawaiian Islands were included, the fixation index was slightly reduced $\left(\Phi_{\mathrm{st}}=0.211\right)$ but remained highly significant $(\mathrm{p}<0.001)$. For the entire dataset, nucleotide diversity was $\pi=0.003$, and haplotype diversity was $h=0.632$. Tajima's D was negative $(d=-1.67)$ for the overall dataset. Mismatch distribution for the overall dataset was unimodal (Harpending's raggedness index $r=0.103, p=0.500$ ) and yielded values of $\tau=6.671, \theta_{0}=0.0$ and $\theta_{1}=2.049$ (Fig. 3). Based on a generation time of $3 \mathrm{yr}$ and a molecular clock estimate of $2 \%$ divergence per $10^{6} \mathrm{yr}$ between lineages, we calculated a coalescence time of $519000 \mathrm{yr}$. Using a range of mutation rates (1 to $3 \%$ per $10^{6} \mathrm{yr}$ between lineages) yielded a range of coalescence times from ca. 300000 to 1000000 yr. Initial effective population size estimate is $N_{\mathrm{e} 0}=0$ and current effective population size is $N_{\mathrm{e} 1}=53000$.

In population pairwise comparisons of the fixation index, 18 out of 20 comparisons involving the IO sites 


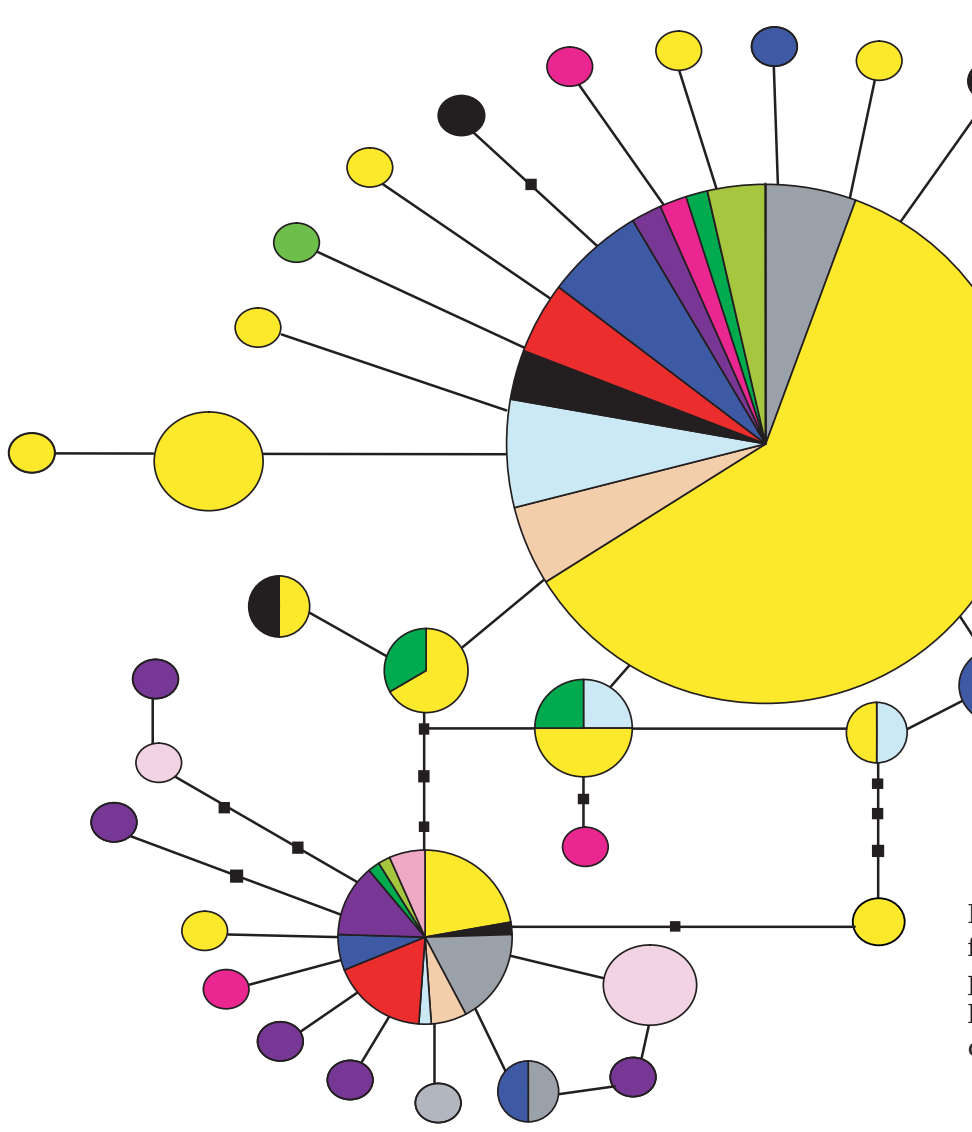

Panama

Clipperton Atoll

Hawaii (All)

Christmas Is. (Kiribati)

Canton Island

Marquesas Islands

Moorea

Okinawa

Akajima

Lizard Island

Cocos-Keeling Is.

Seychelles

Fig. 2. Myripristis berndti. Statistical parsimony network for 278 cytochrome $b$ sequences. Area of circles is proportional to number of individuals with particular haplotype; small squares indicate missing haplotypes; colors represent collection locality (see key). Includes all samples from Hawaiian Islands

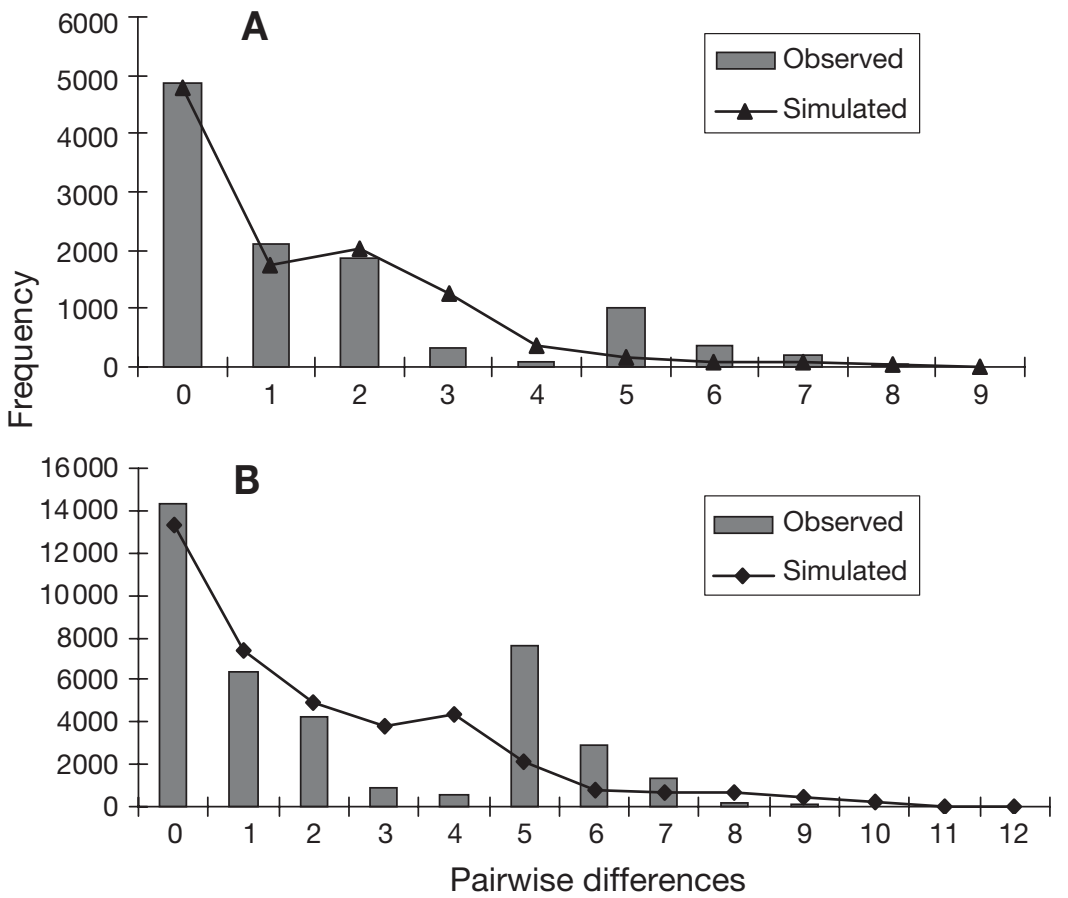

Fig. 3. Myripristis berndti. Mismatch distributions for cytochrome $b$ haplotypes: (A) Hawaii $(\mathrm{N}=147)$; (B) across the range of the species $(\mathrm{N}=278)$. Harpending's raggedness indices were $r=0.09(\mathrm{p}=0.65)$ for $\mathrm{A}$, and $r=0.1(\mathrm{p}=0.50)$ for $\mathrm{B}$ were significant (Table 2). This significance falls away in 5 of the 18 significant comparisons following Bonferroni correction for multiple comparisons (i.e. dividing cutoff for significance, in this case $p=0.05$, by the total number of comparisons). The IO sites harbor more unique haplotypes than any other site (Fig. 2, Table 1) which may be contributing to greater structure than observed elsewhere.

Within the CWP, pairwise comparisons of fixation index ranged from $\Phi_{\text {st }}$ $=-0.111$ to 0.099 (all non significant) and overall no structure was observed within this region $\left(\Phi_{\mathrm{st}}=-0.007, \mathrm{p}=\right.$ 0.634). Similarly, no significant comparisons were recovered for sites within either the IO or EP sites. Notably, however, our Indian Ocean sample sizes were small, and these results are interpreted with caution. Comparisons of fixation index between TEP and CWP ranged from $\Phi_{\mathrm{st}}=0.107$ to 0.424 (16 comparisons) and between CWP and IO sites from 
Table 1. Myripristis berndti. Molecular diversity indices for 278 cytochrome $b$ haplotypes. * : significant at $p=0.05$

\begin{tabular}{|c|c|c|c|c|c|c|}
\hline Site & $\mathrm{N}$ & $\begin{array}{c}\text { No. of } \\
\text { haplotypes }\end{array}$ & $\begin{array}{l}\text { No. of unique } \\
\text { haplotypes }\end{array}$ & $\begin{array}{l}\text { Haplotype } \\
\text { diversity }\end{array}$ & $\begin{array}{c}\text { Nucleotide } \\
\text { diversity }\end{array}$ & $\begin{array}{c}\text { Tajima's } \\
\text { D }\end{array}$ \\
\hline \multicolumn{7}{|l|}{ East Pacific } \\
\hline Panama & 19 & 4 & 1 & $0.626 \pm 0.066$ & $0.004 \pm 0.002$ & 1.39 \\
\hline Clipperton & 15 & 2 & 1 & $0.533 \pm 0.051$ & $0.004 \pm 0.002$ & 2.47 \\
\hline \multicolumn{7}{|l|}{ Hawaii } \\
\hline Kure & 16 & 8 & 1 & $0.700 \pm 0.127$ & $0.003 \pm 0.002$ & -1.47 \\
\hline Midway & 22 & 7 & 1 & $0.597 \pm 0.118$ & $0.003 \pm 0.002$ & -1.25 \\
\hline Pearl \& Hermes & 5 & 2 & 0 & $0.600 \pm 0.175$ & $0.004 \pm 0.003$ & 1.68 \\
\hline French Frigate Shoals & 31 & 9 & 0 & $0.624 \pm 0.098$ & $0.002 \pm 0.001$ & $-1.72^{*}$ \\
\hline Niihau & 8 & 4 & 1 & $0.643 \pm 0.184$ & $0.001 \pm 0.001$ & -1.44 \\
\hline Kauai & 3 & 2 & 0 & $0.667 \pm 0.314$ & $0.001 \pm 0.001$ & 0.00 \\
\hline Molokai & 18 & 5 & 1 & $0.484 \pm 0.138$ & $0.002 \pm 0.001$ & -1.28 \\
\hline Lanai & 13 & 4 & 0 & $0.423 \pm 0.164$ & $0.001 \pm 0.001$ & $-1.86^{*}$ \\
\hline Hawaii & 31 & 7 & 0 & $0.416 \pm 0.109$ & $0.001 \pm 0.001$ & $-2.02^{*}$ \\
\hline All Hawaiian Islands & 147 & 18 & & $0.553 \pm 0.048$ & $0.002 \pm 0.001$ & $-1.55^{*}$ \\
\hline \multicolumn{7}{|l|}{ Central West Pacific } \\
\hline Marquesas & 18 & 7 & 0 & $0.634 \pm 0.126$ & $0.001 \pm 0.001$ & $-1.80^{*}$ \\
\hline Moorea & 18 & 7 & 3 & $0.686 \pm 0.112$ & $0.003 \pm 0.002$ & -0.97 \\
\hline Kiribati & 12 & 3 & 0 & $0.530 \pm 0.135$ & $0.003 \pm 0.002$ & -0.33 \\
\hline Canton Island & 7 & 6 & 1 & $0.952 \pm 0.095$ & $0.003 \pm 0.002$ & -0.86 \\
\hline Lizard Island WP & 9 & 5 & 2 & $0.722 \pm 0.152$ & $0.003 \pm 0.002$ & $-1.59^{*}$ \\
\hline \multicolumn{7}{|l|}{ West Pacific } \\
\hline Akajima & 6 & 4 & 2 & $0.800 \pm 0.172$ & $0.004 \pm 0.003$ & -1.12 \\
\hline Okinawa & 7 & 2 & 0 & $0.286 \pm 0.196$ & $0.002 \pm 0.001$ & $-1.48^{*}$ \\
\hline \multicolumn{7}{|l|}{ Indian Ocean } \\
\hline Cocos-Keeling & 5 & 3 & 2 & $0.700 \pm 0.218$ & $0.002 \pm 0.002$ & -1.09 \\
\hline Seychelles & 15 & 8 & 5 & $0.829 \pm 0.084$ & $0.004 \pm 0.003$ & -1.42 \\
\hline All samples & 278 & 37 & & $0.632 \pm 0.031$ & $0.003 \pm 0.002$ & $-1.67^{*}$ \\
\hline
\end{tabular}

$\Phi_{\text {st }}=0.329$ to 0.810 (16 comparisons). In the above comparisons of sites from the TEP and CWP (i.e. sites across the EPB) 7 of 16 comparisons were statistically significant, while all of 16 comparisons from sites across the CWP and IO (i.e. the IPB) were statistically significant (Table 2). Across each of these comparisons, we note higher values of $\Phi_{\text {st }}$ between the IO and CWP basins than across the entire Pacific Ocean basin (i.e. CWP + EP) and the ranges of values for IO and CWP vs. CWP and TEP were significantly different (Mann-Whitney $U$-test; $\mathrm{p}<0.001$ ).

When grouped by major biogeographic province, fixation index was highest when comparing the IO and CWP groups $\left(\Phi_{\text {st }}=0.583, \mathrm{p}<0.001\right)$ than when comparing the TEP with the $\operatorname{CWP}\left(\Phi_{\mathrm{st}}=0.278, \mathrm{p}<\right.$ 0.001) (Table 3). Within the CWP alone, fixation index

Table 2. Myripristis berndti. Population pairwise $\Phi_{\mathrm{st}}$ values of 278 cytochrome $b$ sequences across 12 sample localities (below diagonal) and associated $p$-values (above diagonal). ${ }^{*}$ : significant at $p=0.05{ }_{i}^{* *}$ : significance following Bonferroni correction $(p=0.004)$

\begin{tabular}{|c|c|c|c|c|c|c|c|c|c|c|c|c|}
\hline & Panama & Clipperton & $\begin{array}{c}\text { Big } \\
\text { Island }\end{array}$ & Marquesas & Moorea & Kiribati & $\begin{array}{l}\text { Canton } \\
\text { Island }\end{array}$ & Akajima & Okinawa & $\begin{array}{l}\text { Lizard } \\
\text { Island }\end{array}$ & $\begin{array}{l}\text { Cocos- } \\
\text { Keeling }\end{array}$ & Seychelles \\
\hline Panama & - & 0.991 & $0^{* *}$ & $0.009^{*}$ & $0.009^{*}$ & 0.171 & 0.171 & 0.162 & 0.198 & $0.027^{*}$ & $0.045^{*}$ & 0.135 \\
\hline Clipperton & -0.061 & - & $0^{* *}$ & $0.018^{*}$ & $0.045^{*}$ & 0.144 & 0.135 & 0.126 & 0.180 & 0.054 & $0.036^{*}$ & 0.225 \\
\hline Big Island & 0.393 & 0.424 & - & 0.613 & 0.225 & 0.054 & 0.099 & 0.117 & 0.739 & 0.162 & $0^{* *}$ & $0^{* *}$ \\
\hline Marquesas & 0.307 & 0.333 & -0.009 & - & 0.604 & 0.252 & 0.532 & 0.279 & 0.964 & 0.577 & $0^{* *}$ & $0^{* *}$ \\
\hline Moorea & 0.177 & 0.189 & 0.029 & -0.014 & - & 0.640 & 0.721 & 0.586 & 0.937 & 0.739 & $0^{* *}$ & $0^{* *}$ \\
\hline Kiribati & 0.074 & 0.083 & 0.099 & 0.037 & -0.045 & - & 0.919 & 0.514 & 0.991 & 0.496 & $0^{* *}$ & $0^{* *}$ \\
\hline Canton Island & 0.106 & 0.120 & 0.049 & -0.012 & -0.067 & -0.094 & - & 0.874 & 0.991 & 0.847 & $0^{* *}$ & $0^{* *}$ \\
\hline Akajima & 0.107 & 0.114 & 0.091 & 0.000 & -0.044 & -0.069 & -0.103 & - & 0.523 & 0.658 & $0.009^{*}$ & $0.036^{*}$ \\
\hline Okinawa & 0.167 & 0.185 & -0.029 & -0.063 & -0.093 & -0.087 & -0.111 & -0.096 & - & 0.991 & $0^{* *}$ & $0.009^{*}$ \\
\hline Lizard Island & 0.191 & 0.204 & 0.011 & -0.012 & -0.043 & -0.037 & -0.076 & -0.055 & -0.105 & - & $0^{* *}$ & $0^{* *}$ \\
\hline Cocos-Keeling & 0.268 & 0.276 & 0.810 & 0.761 & 0.627 & 0.568 & 0.598 & 0.550 & 0.705 & 0.650 & - & 0.568 \\
\hline Seychelles & 0.073 & 0.067 & 0.624 & 0.544 & 0.424 & 0.329 & 0.351 & 0.336 & 0.421 & 0.423 & -0.027 & - \\
\hline
\end{tabular}


Table 3. Myripristis berndti. AMOVA hierarchical comparisons of cytochrome $b$ sequence data. TEP: tropical eastern Pacific; CWP: central-western Pacific; IO: Indian Ocean; ns: not significant

\begin{tabular}{|lrc|}
\hline Comparison & $\Phi_{\text {st }}$ & $\mathrm{p}$ \\
\hline TEP vs CWP & 0.27 & $<0.001$ \\
CWP vs IO & 0.58 & $<0.001$ \\
CWP only & -0.01 & $0.6 \mathrm{~ns}$ \\
IO only & -0.02 & $0.5 \mathrm{~ns}$ \\
TEP only & -0.06 & $0.9 \mathrm{~ns}$ \\
\hline
\end{tabular}

was not significantly different from zero $\left(\Phi_{\mathrm{st}}=-0.007\right.$, $\mathrm{p}=0.634)$. Likewise, within the TEP and IO $\Phi_{\text {st }}$ was not significantly different from zero $\left(\Phi_{\mathrm{st}}=-0.061, \mathrm{p}=\right.$ $0.920, \Phi_{\text {st }}=-0.027, p=0.528$, respectively; Table 3).

\section{DISCUSSION}

\section{Population structure}

Our survey of bigscale soldierfish indicated no population structure across the $2500 \mathrm{~km}$ length of the Hawaiian archipelago, yet significant structure was revealed across the entire $24000 \mathrm{~km}$ range of the species. This sampling strategy with robust comparisons on 2 spatial scales indicates strong connectivity over a vast range. Our results suggest that the intermittent IPB is more effective at preventing gene flow (dispersal) than the vast expanse of the EPB $\left(\Phi_{\mathrm{st}}=0.583, \mathrm{p}<\right.$ $0.001 ; \Phi_{\mathrm{st}}=0.278, \mathrm{p}<0.001$, respectively).

One unusual outcome is the apparent lack of structure between TEP and IO samples from the Seychelles (i.e. sites at the opposite extremes of the species range). Pairwise comparisons of $\Phi_{\text {st }}$ between the Seychelles and both Clipperton and Panama are effectively zero (Table 2). This occurs despite the fact that the Cocos-Keeling sample, which has a lower sample size than the Seychelles, was significantly different from both Clipperton and Panama in pairwise comparisons of $\Phi_{\mathrm{st}}$. While this pattern may reflect low sample sizes obtained from IO and TEP sites, sample sizes alone do not readily explain that pattern. As recent geneflow is unlikely, this and other patterns may be caused by some degree of genetic drift.

\section{Range size, biogeography and connectivity}

Given the vast range of this reef inhabitant it is surprising to find only a moderate degree of population structure (overall $\Phi_{\mathrm{s}}=0.211, \mathrm{p}<0.001$ ). Pairwise comparisons of $\Phi_{\mathrm{s}}$ within the TEP, CWP, and IO are essentially $\Phi_{\text {st }}=0$, while values between TEP and CWP range from $\Phi_{\text {st }}=0.114$ to 0.424 (overall $\Phi_{\mathrm{st}}=0.278$ ), and between Pacific and Indian basins from $\Phi_{\text {st }}=0.329$ to 0.810 (overall $\Phi_{\text {st }}=0.583$ ). We noted higher divergence between the IO and CWP basins than across the entire Pacific basin, i.e. between CWP and TEP. This pattern is also reflected when sample sites are grouped by major biogeographic province (Table 3). We interpret the lack of structure across the entire CWP as evidence that these patterns are not a reflection of isolation by distance. By comparison, Lessios \& Robertson (2006) showed a range of $\Phi_{\mathrm{ct}}=0$ to 0.48 in a genetic survey of 20 species across the EPB, while Bowen et al. (2006b) show a range of $\Phi_{\mathrm{st}}=0.01$ to $0.93\left(\right.$ mean $\left.\Phi_{\mathrm{st}}=0.55\right)$ in a survey of 15 species in comparisons of trans-Atlantic $(\sim 3500 \mathrm{~km}$ of deep ocean) and trans-Amazonian $(\sim 2300 \mathrm{~km}$ of freshwater) connectivity. Among these 15 Atlantic species, the congener Myripristis jacobus, which is distributed throughout the tropical Atlantic, had the lowest population structure (Bowen et al. 2006b). Other reef fishes show strong genetic structure over scales $<1000$ km (e.g. Rocha et al. 2005a,b, Taylor \& Hellberg 2005).

\section{Relative effectiveness of two major dispersal barriers}

Our data indicate that the biogeographic barrier represented by the Indo-Malaysian archipelago and Australia is more effective than the EPB. The EPB is apparently a 'soft' water barrier, which is permeable to low levels of dispersal (Lessios \& Robertson 2006). In contrast, the IPB is a 'hard' barrier in which large land areas of the island archipelagos and Australia physically prevent dispersal. Moreover, the IPB is intermittent, with enhancements during glacial periods due to increases in the extent of land area, and strong upwelling in the only channel connecting the Indian and Pacific Oceans at such times (Fleminger 1986).

Although the $\Phi_{\text {st }}$ values indicate significant population structure, the widespread distribution of cytochrome $b$ haplotypes in Myripristis berndti is unprecedented for an obligate reef fish. As shown in the statistical parsimony network (Fig. 2), the most common haplotypes are present at nearly every sampling locality. This implies recent dispersal on the scale of several thousand $\mathrm{km}$ and is reflected in the range of the species which spans 2 ocean basins (Indian and Pacific) and multiple biogeographic regions (TEP, CWP, IO). The pattern of shared haplotypes across such a vast range is more similar to that seen in some pelagic fishes (e.g. Graves 1998) than in reef fishes. The great-circle distance from the Panamanian coast to the Seychelles is ca. $24000 \mathrm{~km}$, or roughly $2 / 3$ Earth's radius. Relatively few species of marine fishes ( 60 
species or $1 \%$ of total Indo-Pacific reef-fish fauna; Robertson et al. 2004) are known to occur over such large geographic areas; those that do may include subspecies or cryptic evolutionary lineages (e.g. Knowlton 1993). We find no sharp genetic breaks that would indicate such evolutionary partitions, consistent with previous morphological assessments (Randall \& Greenfield 1996).

\section{Ice ages, population expansions and deep reefs as refugia}

One surprising result of this survey is that both the mismatch distribution and Tajima's test of neutrality indicate recent population expansions for both the overall dataset and for the Hawaiian Island group, as well as a relatively recent coalescent time (300000 to 1000000 yr; Table 1, Fig. 3). In other shallow-water fishes, this signature is attributed to severe population reductions due to habitat alterations during Plio-Pleistocene periods of lowered sea-level, followed by rapid population growth after the glacial ice retreat (Grant \& Bowen 1998). Reef organisms whose primary habitat is shallow water or lagoon are presumably displaced and/or locally extirpated during these periods (Daly 1915), causing a severe genetic bottleneck (e.g. Fauvelot et al. 2003). As sea-level rises following these events, population expansions result in an abundance of low frequency haplotypes.

While Myripristis berndti has been observed on deep reefs, its range is concentrated in the upper $50 \mathrm{~m}$ (J. Earle pers. comm.) and the species is considered to be an outer reef specialist (i.e. it does not inhabit lagoons). Populations of this species would not have been displaced to the same degree as shallow reef or lagoon specialists. Deep reef refugia may have buffered local populations to some extent; however, $M$. berndti has the shallow gene genealogy (Fig. 3) and recent coalescence time characteristic of many shallow reef fishes. Hence, a broad geographic and depth distribution does not seem to infer greater population stability in $M$. berndti. It must be noted that while the available habitat may have been sufficient to maintain a large population during glacial low stands, a disruption of the overall community structure, including food sources, predators and interacting species may have induced population crashes. Other factors, such as high variance in reproductive success, may also contribute to this pattern (Grant \& Bowen 1998, Planes \& Lenfant 2002). It remains to be seen, however, if this signature of shallow population structure is found in deep reef specialists, which would be least affected by fluctuations in sea level.
Habitat alterations during glacial episodes, however, may explain the greater population structure between Indian Ocean and Pacific sampling localities (Table 2). During these Plio-Pleistocene low stands, a much greater landmass lay between the Indian and Pacific Ocean basins (Hontoro 1997, Voris 2000) creating a near complete physical barrier that was much less penetrable by larvae. This geologically intermittent barrier has influenced the biogeography of many marine species (Barber et al. 2000, 2002) and may act as a selective filter for organisms with high dispersal capabilities.

\section{Small scale connectivity and marine reserves}

The Hawaiian Islands are comprised of 2 regions: the basalt islands of the southeast and the numerous coralline reefs and atolls of the Northwestern Hawaiian Islands, which have recently received the protected status of a National Monument (NWHIMNM; Fig. 1). The latter area stretches from the island of Nihoa in the south, northwest to Kure Atoll ( 2000 km; Fig. 1) and provides a prime setting for examination of medium-scale phylogeographic patterns. The sampling of the Hawaiian Islands represents a scale and intensity that has been matched only once previously. Rivera et al. (2004) conducted a similar mtDNA survey for the Hawaiian grouper Epinephelus quernus and demonstrated subtle but significant population structure across the same span of the Hawaiian Islands using the mitochondrial control region $\left(\max \Phi_{\mathrm{st}}=0.06, \mathrm{p}<0.01\right)$. In contrast, our survey of bigscale soldierfish across the same geographic scale shows an order of magnitude less structure $\left(\Phi_{\mathrm{st}}=0.005\right.$, $\mathrm{p}=0.0414)$. For Myripristis berndti we find no evidence for a restriction in gene flow between these 2 areas. This indicates that the populations have been and are still most likely connected by larval dispersal. However, we cannot rule out adult movement across deep oceanic stretches, or that this signal is a reflection of recent, past range expansions that have yet to reach genetic equilibrium. Our results indicate that for species with a high dispersal potential, the main 8 and the NW Hawaiian Islands are connected, at least in genetic terms. However, surveys of additional species are necessary to test the generality of this finding.

\section{Connectivity and dispersal in Myripristis berndti}

In recent years there has been a paradigm shift in the understanding of reef fish dispersal, with a new emphasis on self-recruitment and larval retention (e.g. Jones et al. 2005, Cowen et al. 2006). Additionally, larval behavior is known to affect dispersal potential 
(Leis 2002). While it is important to note that studies showing high self recruitment reflect patterns on the scale of single generations and our results likely reflect scales of $10^{2}$ to $10^{3}$ generations, these developments do not belie the fact that some reef fishes disperse tremendously during early life history stages. Examples include the pygmy angelfishes (genus Centropyge; Bowen et al. 2006b, Schultz et al. 2007), trumpetfishes (genus Aulostomus; Bowen et al. 2001), Myripristis jacobus (Bowen et al. 2006a) and now M. berndti.

The relationship between the strong genetic connectivity of scattered Myripristis berndti populations and pelagic dispersal potential remains tenuous. The largest oceanic distance in the broader Indo-Pacific region is across the EPB. Although current flows can typically carry a parcel of water across the EPB in 100 to $155 \mathrm{~d}$, during El Niño events this transit time may be reduced to 50 to 80 d (Firing et al. 1983, Wyrtki 1985, Richmond 1990). Thus it is possible that a PLD slightly longer than the preliminary estimate of $55 \mathrm{~d}$ for $M$. berndti may be sufficient to maintain the observed levels of genetic connectivity. However, it is also quite possible that an extended, post-larval oceanic phase in soldierfishes augments dispersal ability. In the related genus Holocentrus, a pelagic 'meeki' stage follows the spiny rhynchichthys phase during development. The name for this stage is a reflection of an invalidated species description for this juvenile phase (Holocentrus meeki Bean 1905). While this juvenile stage is known only in the genus Holocentrus, it is possible that an analogous, protracted juvenile stage occurs in Myripristis spp. (R. Rosenblatt \& G. D. Johnson pers. comm.). The planktivorous feeding habits of both adults and pelagic juveniles indicate that an extended pelagic juvenile phase (postrhynchichthys) could extend well past the larval-juvenile transition. The presence of this additional stage would allow juveniles to persist in offshore waters a good deal longer than would be expected if settlement was required after metamorphosis. While there are no records of adults of this species in offshore samples that we are aware of, juvenile Myripristis spp. are found in the stomachs of tuna taken by longlines (V. Allain pers. comm.) and pelagic juveniles up to $36 \mathrm{~mm}$ have been collected in plankton tows (G. D. Johnson pers. comm.). Thus the capability of juveniles of this species to utilize offshore, pelagic habitat may impart high dispersal potential and explain the high Indo-Pacific-wide connectivity in M. berndti.

Acknowledgements. We thank the Northwestern Hawaiian Islands Marine National Monument (NWHIMNM) and US Fish and Wildlife Service for coordinating research activities and permitting procedures, and the crews of the NOAA Ship 'Hi'ialakai' and the Smithsonian Institution's RV 'Urraca' for assistance in the field. This work was funded by a grant to
B.W.B. and R. Toonen from the US National Science Foundation (OCE-0454873) and by the HIMB-NWHI Coral Reef Research Partnership (NMSP MOA 2005-008/66882). We thank S. Daley, HIMB Evolutionary Genetics Core Facility, for providing DNA sequences. The HIMB core facility is supported by an EPSCoR grant to University of Hawaii (EPS0554657). Fieldwork by D.R.R. was supported by the Smithsonian Tropical Research Institute, the Seychelles Government Fisheries Department, grants from the National Geographic Society (NGS 5831-96 and 7269-02) and a fellowship from the Japan Society for the Promotion of Science. J.A.E. was funded by the NSF GK-12 Fellowship Program. Thanks to G. D. Johnson, J. Leis, R. Rosenblatt, and B. Victor, for additional life history information and thoughtful discussions of Myripristis dispersal. E. Franklin, NWHIMNM and HIMB kindly provided the map of the NWHIMNM. We thank L. Basch, M. Chow, M. Crepeau, E. DeMartini, J. Earle, R. Klinger, R. Kosaki, C. Meyer, Y. Papastamatiou, J. Randall, L. Rocha, R. Toonen for research coordination, collections, funding, laboratory assistance and valuable advice. This is SOEST Contribution No. 6820 and HIMB Contribution No. 1237.

\section{LITERATURE CITED}

Barber PH, Palumbi SR, Erdmann MV, Kadim Moosa M (2000) A marine Wallace's line? Nature 406:692-693

Barber PH, Palumbi SR, Erdmann MV, Moosa MK (2002) Sharp genetic breaks among populations of Haptosquilla pulchella (Stomatopoda) indicate limits to larval transport: patterns, causes, and consequences. Mol Ecol 11:659-674

Bermingham E, McCafferty SS, Martin AP (1997) Fish biogeography and molecular clocks: Perspectives from the Panamanian Isthmus. In: Stepien C, Kocher T (eds) Molecular systematics of fishes. Academic Press, San Diego, p 113-128

Bowen BW, Bass AL, Rocha LA, Grant WS, Robertson DR (2001) Phylogeography of the trumpetfishes (Aulostomus): ring species complex on a global scale. Evolution 55:1029-1039

Bowen BW, Bass AL, Muss AJ, Robertson DR (2006a) Phylogeography of two Atlantic squirrelfishes (family Holocentridae): Exploring links between pelagic larval dispersal and population connectivity. Mar Biol 149:899-913

Bowen BW, Muss A, Rocha LA, Grant WS (2006b) Shallow mtDNA coalescence in Atlantic pygmy angelfishes (Genus Centropyge) indicates a recent invasion from the Indian Ocean. J Heredity 97:1-12

Briggs JC (1974) Marine zoogoegraphy. McGraw-Hill, New York

Chave EH, Mundy BC (1994) Deep sea benthic fishes of the Hawaiian archipelago, Cross seamount, and Johnston Atoll. Pac Sci 48:367-409

Clement M, Posada D, Crandall KA (2000) TCS: a computer program to estimate gene genalogies. Mol Ecol 9: 1657-1659

Cowen RK, Paris CB, Srinisvasan A (2006) Scaling of connectivity in marine populations. Science 311:522-527

Craig MT, Pondella, DJ II, Hastings PA (2004) Speciation in the Central American Seaway: the importance of taxon sampling in the identification of trans-isthmian geminate pairs. J Biogeogr 31:1085-1091

Crisp DJ (1978) Genetic consequences of different reproductive strategies in marine invertebrates. In: Battaglia B, Beadmore JA (eds) Marine organisms: genetics, ecology and evolution. Plenum, New York, p 257-273

Daly RA (1915) The glacial-control theory of coral reefs. Proc Am Acad Arts Sci 51:155-251 
Durand JD, Tine M, Panfili J, Thiaw OT, Laë R (2005) Impacts of glaciations and geographic distance on the genetic structure of a tropical estuarine fish, Ethmalosa fimbriata (Clupeidae, S. Bodwich 1825). Mol Phylogenet Evol 36: $277-287$

Ekman S (1953) Zoogeography of the sea. Sidgwick \& Jackson, London

Fauvelot C, Bernardi G, Planes S (2003) Reductions in the mitochondrial DNA diversity of coral reef fish provide evidence of population bottlenecks resulting from Holocene sea-level change. Evolution 57:1571-1583

Firing E, Lukas R, Sadler J, Wyrtki K (1983) Equatorial undercurrent disappears during 1982-83 El Niño. Science 222: $1121-1123$

Fleminger A (1986) The Pleistocene equatorial barrier between the Indian and Pacific oceans and a likely cause for Wallace's Line. In: Pierrot-Bolts AC (ed) UNESCO Tech Pap Mar Sci 49, p 84-97

Friedlander AM, DeMartini EE (2002) Contrasts in density, size, and biomass of reef fishes between the northwestern and main Hawaiian Islands: the effects of fishing down apex predators. Mar Ecol Prog Ser 230:253-264

Grant WS, Bowen BW (1998) Shallow population histories in deep evolutionary lineages of marine fishes: insights from sardines and anchovies and lessons for conservation. J Heredity 89:415-426

Graves JE (1998) Molecular insights into the population structures of cosmopolitan reef fishes. J Heredity 89:427-437

Greenfield DW (1968) The zoogeography of Myripristis (Pisces: Holocentridae). Syst Zool 17:76-87

Hantoro WD (1997) Quaternary sea level variations in the Pacific-Indian Ocean Gateways: response and impacts. Quat Int 37:73-80

Hellberg ME, Balch DP, Roy K (2001) Climate driven range expansion and morphological evolution in a marine gastropod. Science 292:1707-1710

Jones GP, Planes S, Thorrold SR (2005) Coral reef fish larvae settle close to home. Curr Biol 15:1314-1318

Klicka J, Zink RM (1997) The importance of recent ice ages in speciation: a failed paradigm. Science 277:1666-1669

Knowlton NK (1993) Sibling species in the sea. Annu Rev Ecol Syst 24:189-216

Knowlton NK, Weight LA (1998) New dates and new rates for divergence across the Isthmus of Panama. Proc R Soc Lond B 265:2257-2263

Leis JM (2002) Pacific coral reef fishes: the implications of behavior and ecology of larvae for biodiversity and conservation, and a reassessment of the open population paradigm. Environ Biol Fishes 65:199-208

Leis JM, Carson-Ewert BM (1997) In situ swimming speeds of the late pelagic larvae of some Indo-Pacific coral reef fishes. Mar Ecol Prog Ser 159:165-174

Lessios HA, Robertson DR (2006) Crossing the impassible: Genetic connections in 20 reef fishes across the eastern Pacific barrier. Proc R Soc Lond Ser B 273:2201-2208

Li WH (1977) Distribution of nucleotide differences between 2 randomly chosen cistrons in a finite population. Genetics, 85:331-337

Nei M (1987) Molecular evolutionary genetics. Columbia University Press, New York

Planes S, Lenfant P (2002) Temporal change in the genetic structure between and within cohorts of a marine fish, Diplodus sargus, induced by a large variance in individual reproductive success. Mol Ecol 11:1515-1524
Randall JE, Greenfield DW (1996) Revision of the Indo-Pacific Holocentrid fishes of the genus Myripristis, with description of three new species. Indo-Pacific Fishes 25. Bishop Museum, Honolulu

Richmond RH (1990) The effects of El Niño/Southern Oscillation on the dispersal of corals and other marine organisms. In: Glynn PWG (ed) Global ecological consequences of the 1982-83 El Niño Southern Oscillation. Elsevier, Amsterdam, p 153-190

Rivera MJ, Kelley CD, Roderick GK (2004) Subtle population genetic structure in the Hawaiian grouper, Epinephelus quernus (Serranidae) as revealed by mitochondrial DNA analysis. Biol J Linn Soc 81:449-468

Robertson, DR, Grove JS, McCosker JE (2004) Tropical transpacific shorefishes. Pac Sci 58:507-565

Rocha LA, Robertson DR, Roman J, Bowen BW (2005a) Ecological speciation in tropical reef fishes. Proc R Soc Lond Ser B 272:573-579

Rocha LA, Robertson DR, Rocha CR, Van Tassell JL, Craig MT, Bowen BW (2005b) Recent invasion of the tropical Atlantic by an Indo-Pacific coral reef fish. Mol Ecol 14: 3921-3928

Rogers AR, Harpending H (1992) Population growth makes waves in the distribution of pairwise genetic differences. Mol Biol Evol 9:552-569

Roy K, Valentine JW, Jablonski D, Kidwell SM (1996) Scales of climatic variability and time averaging in Pleistocene biotas: implications for ecology and evolution. Trends Ecol Evol 11:158-163

Scheltema RS (1968) Dispersal of larvae by equatorial ocean currents and its importance to the zoogeography of shoalwater tropical species. Nature 217:1159-1162

Schultz JK, Pyle RL, DeMartini E, Bowen BW (2007) Genetic connectivity among color morphs and Pacific archipelagos for the flame angelfish, Centropyge loriculus. Mar Biol 151:167-175

Song CB, Near TJ, Page JM (1998) Phylogenetic relations among Percid fishes as inferred from mitochondrial cytochrome $b$ DNA sequence data. Mol Phylogenet Evol 10:343-353

Taberlet P, Meyer A, Bouvet J (1992) Unusually large mitochondrial variation in populations of the blue tit, Parus caeruleus. Mol Ecol 1:27-36

Tajima F (1989) Statistical method for testing the neutral mutation hypothesis by DNA polymorphism. Genetics 123:585-596

Taylor MS, Hellberg ME (2005) Marine radiations at small geographic scales: speciation in neotropical reef gobies (Elacatinus). Evolution 59:374-385

Tyler JC, Johnson GD, Brothers EB, Tyler DM, Smith LC (1993) Comparative early life histories of western Atlantic squirrelfishes (Holocentridae): age and settlement of rhynchichthys, meeki, and juvenile stages. Bull Mar Sci 53:1126-1150

Voris HK (2000) Maps of Pleistocene sea levels in Southeast Asia: shorelines, river systems and time durations. J Biogeogr 27:1153-1167

Wyatt JR (1983) The biology, ecology and bionomics of the squirrelfishes, Holocentridae. In: Munro JL (ed) Caribbean coral reef fishery resources. ICLARM Stud. Rev. 7, p 50-58. Also: Res Rep Zool Dep Univ West Indies 3:1-41, 1976

Wyrtki K (1985) Sea level fluctuations in the Pacific during the 1982-83 El Niño. Geophys Res Lett 12:125-128

Submitted: April 26, 2006; Accepted: September 14, 2006 Proofs received from author(s): March 21, 2007 